Article

\title{
Suppression of Grape White Rot Caused by Coniella vitis Using the Potential Biocontrol Agent Bacillus velezensis GSBZ09
}

\author{
Xiangtian Yin ${ }^{\dagger}$, Tinggang $\mathrm{Li}^{\dagger}$, Xilong Jiang, Xiaoning Tang, Jiakui Zhang, Lifang Yuan * and Yanfeng Wei * \\ Shandong Academy of Grape, Shandong Academy of Agricultural Sciences, Jinan 250100, China; \\ yinxiangtian@shandong.cn (X.Y.); litinggang@shandong.cn (T.L.); jiangxilong@shandong.cn (X.J.); \\ tangxiaoning@shandong.cn (X.T.); Zhangjiakui@shandong.cn (J.Z.) \\ * Correspondence: Yuanlifang@shandong.cn (L.Y.); weiyanfeng@shandong.cn (Y.W.); \\ Tel.: +86-0531-8559-8079 (L.Y. \& Y.W.) \\ † These authors contributed equally to this work.
}

check for updates

Citation: Yin, X.; Li, T.; Jiang, X.; Tang, X.; Zhang, J.; Yuan, L.; Wei, Y. Suppression of Grape White Rot Caused by Coniella vitis Using the Potential Biocontrol Agent Bacillus velezensis GSBZ09. Pathogens 2022, 11, 248. https://doi.org/10.3390/ pathogens 11020248

Academic Editors: Flora Pensec and Xin Guan

Received: 27 December 2021

Accepted: 1 February 2022

Published: 14 February 2022

Publisher's Note: MDPI stays neutral with regard to jurisdictional claims in published maps and institutional affiliations.

Copyright: (c) 2022 by the authors. Licensee MDPI, Basel, Switzerland. This article is an open access article distributed under the terms and conditions of the Creative Commons Attribution (CC BY) license (https:// creativecommons.org/licenses/by/ $4.0 /)$.

\begin{abstract}
Grape white rot caused by Coniella vitis is prevalent in almost all grapevines worldwide and results in a yield loss of $10-20 \%$ annually. Bacillus velezensis is a reputable plant growth-promoting bacterial. Strain GSBZ09 was isolated from grapevine cv. Red Globe (Vitis vinifera) and identified as B. velezensis according to morphological, physiological, biochemical characteristics and a multilocus gene sequence analysis (MLSA) based on six housekeeping genes (16S rRNA, gyrB, rpoD, atpD, rho and $p g k)$. B. velezensis GSBZ09 was screened for antifungal activity against $C$. vitis under in vitro and in vivo conditions. GSBZ09 presented broad spectrum antifungal activity and produced many extracellular enzymes that remarkably inhibited the mycelial growth and spore germination of $C$. vitis. Furthermore, GSBZ09 had a high capacity for indole-3-acetic acid (IAA) production, siderophore production, and mineral phosphate solubilization. Pot experiments showed that the application of GSBZ09 significantly decreased the disease index of the grape white rot, directly promoted the growth of grapes, and upregulated defense-related enzymes. Overall, the features of B. velezensis GSBZ09 make it a potential strain for application as a biological control agent against C. vitis.
\end{abstract}

Keywords: biocontrol agent; Bacillus velezensis; antagonistic activity; grape white rot; Coniella vitis

\section{Introduction}

Grape white rot (hail disease) is prevalent in almost all grapevines worldwide, and it severely affects grape growth and results in a yield loss of $10-20 \%$ annually $[1,2]$. Coniella vitis is considered to be the main pathogen of the disease in China [3], although white rot can also be caused by C. doplodiella (Speg.) petr. and Syd. [4], C. fragariae (Oudem) B. Sutton, and Pilidiella cataneicola [5]. C. vitis mainly infects ripening berries, but also damages the green tissues of the vine [6]. Infected berries finally became soft and rotten and covered with pycnidia of grayish-white color. In addition, this seriously affects the quality and nutrition of grapes, with a production loss of $16.3 \%$ in China [3].

Plant growth-promoting rhizobacteria (PGPR) are bacteria that can promote plant growth. The mechanisms of PGPR mainly include the production of indole-3-acetic acid (IAA), fixation of nitrogen, dissolution of phosphorus, dissolution of potassium, secretion of ferriphagin, and secretion of plant hormones and related regulatory substances $[7,8]$. The ability of IAA biosynthesis in Bacillus varies depending on the species [9,10]. B. velezensis group strains are reputed to be PGPR. The production of IAA and cytokinin, both of which are associated with plant growth promotion, were also observed in $B$. velezensis [11,12]. PGPR have the ability to solubilize inorganic and/or organic phosphate from soil. B. velezensis ZF2 was identified as a plant growth-promoting biocontrol agent with the ability to produce IAA and solubilize mineral phosphate [13].

To date, 19 species of Bacillus have been isolated and identified, including B. cereus, B. thuringiensis, B. subtilis, B. anthracis, B. atrophaeus, and B. amyloliquefacies [7]. Previous 
studies demonstrated that $B$. velezensis was a heterotypic synonym of $B$. amyloliquefaciens based on DNA-DNA relatedness values [14]. Currently, B. velezensis can be distinguished from B. amyloliquefaciens and B. subtilis based on multilocus sequence analysis (MLSA) [13]. $B$. velezensis can grow under different environmental conditions with a wide range of temperature adaptations $\left(15-45^{\circ} \mathrm{C}\right)$ and exhibits tolerance to strong acids or strong alkalinity (pH 5-10) [15]. In addition, these species can grow in high salt concentrations of up to $12 \%$ $\mathrm{NaCl}$ and $2 \mathrm{~g} / \mathrm{kg} \mathrm{NaCl}$ in soil and is resistant to many antibiotics, including amoxicillin, ampicillin, rifampicin, fosfomycin, cefotaxime, cephalothin, piperacillin, streptomycin, sulfamethoxazole, ticarcillin, and trimethoprim [16,17].

As a member of the PGPR family, Bacillus has been widely used in disease prevention and control for crops and animals [18,19]. B. altitudinis GLB194 and B. pumilus GLB197 have strong inhibitory activities against grape downy mildew $[20,21]$, and B. cereus NRKT can increase the content of resveratrol in grapes and further reduce the occurrence of grape anthracnose [22]. B. velezensis was first described in southern Spain in 2005 [23], and recently, it was considered a potential biocontrol agent for controlling plant diseases due to its ability to stably colonize the rhizosphere of plants or the soil environment and provide nutrients for plant development. B. velezensis can produce fungal cell wall-degrading enzymes, which is an important mechanism for inhibiting pathogens [11]. Moreover, gene clusters for the biosynthesis of secondary metabolites were identified in $B$. velezensis, including surfactin, iturin, bacillomycin, fengycin, mycosubtilin, bacillaene, and bacilysin, most of which exhibit a wide range of antimicrobial activities [24]. B. velezensis strain KOF112 was isolated from the xylem of grape buds, showed good antifungal activity against Botrytis cinerea, Colletotrichum gloeosporioides and Plasmopara viticola, and significantly upregulated the expression of genes encoding class IV chitinases and $\beta-1,3$ glucanase in grape leaves [25]. B. velezensis Bvel1 produces various metabolites, including iturin $\mathrm{A} 2$, surfactin-C13 and C15, oxydifficidin, bacillibactin, 1-dihydro anticapsin and azelaic acid [26].

Grape white rot caused by $C$. vitis has significantly affected the grape industry. Biological control is considered safer and more non-polluting than chemical prevention, considering grapes are usually used as a fresh fruit and for wine production. To obtain an effective strain for exploiting microbial agents to control grape white rot, in this study, B. velezensis strain GSBZ09, which has antagonistic activities against a broad range of fungal and bacterial pathogens in grapes, was isolated from the rhizosphere soil of grapevines. The biocontrol effect on grape white rot, antifungal mechanism and the plant growthpromoting ability of GSBZ09 were evaluated under both in vitro and in vivo conditions.

\section{Results}

\subsection{Biocontrol Effect of B. velezensis GSBZ09 against Plant Pathogens}

Fifty strains of Bacillus were isolated from rhizosphere soil of vineyards, of which nine strains exhibited antifungal activity against $C$. vitis and had a mycelial growth inhibition rate higher than 50\% (Figure S1). Among these nine strains, GSBZ09 had the strongest antifungal activity against $C$. vitis, with a mycelial growth inhibition rate of $64.44 \%$ (Figure $1 \mathrm{~A}$ ). The mycelial growth inhibition rates of culture filtrates at $20 \%$ and $1 \%$ were $95 \%$ and $42 \%$, respectively (Figure S2A-C). The marginal hyphae inhibited by GSBZ09 had a significantly thick and curved morphology, showed more branches and exhibited tips that expanded into spheres, with the protoplasm flowing out (Figure S2F,G). Spore germination of $C$. vitis was significantly inhibited by dilution of the culture filtrate with an inhibition ratio of $90 \%$. Microscopic observations revealed that the germ tube could not elongate, both the center of the germ tube and the spores swelled, and the contents leaked out (Figure S2D,E). In addition, strain GSBZ09 showed a broad antifungal and antibacterial spectrum, including activity against Gloeosporium fructigrum, B. cinerea, Diaporthe eres, Alternaria viticola, Fusarium oxysporum, Aspergillus niger, Pestalotiopsis clavispora, and Allorhizobium vitis. The inhibition rates on G. fructigrum, B. cinerea, and P. clavispora were $62.58 \%, 68.15 \%$ and $71.85 \%$, respectively (Figure 1B). 

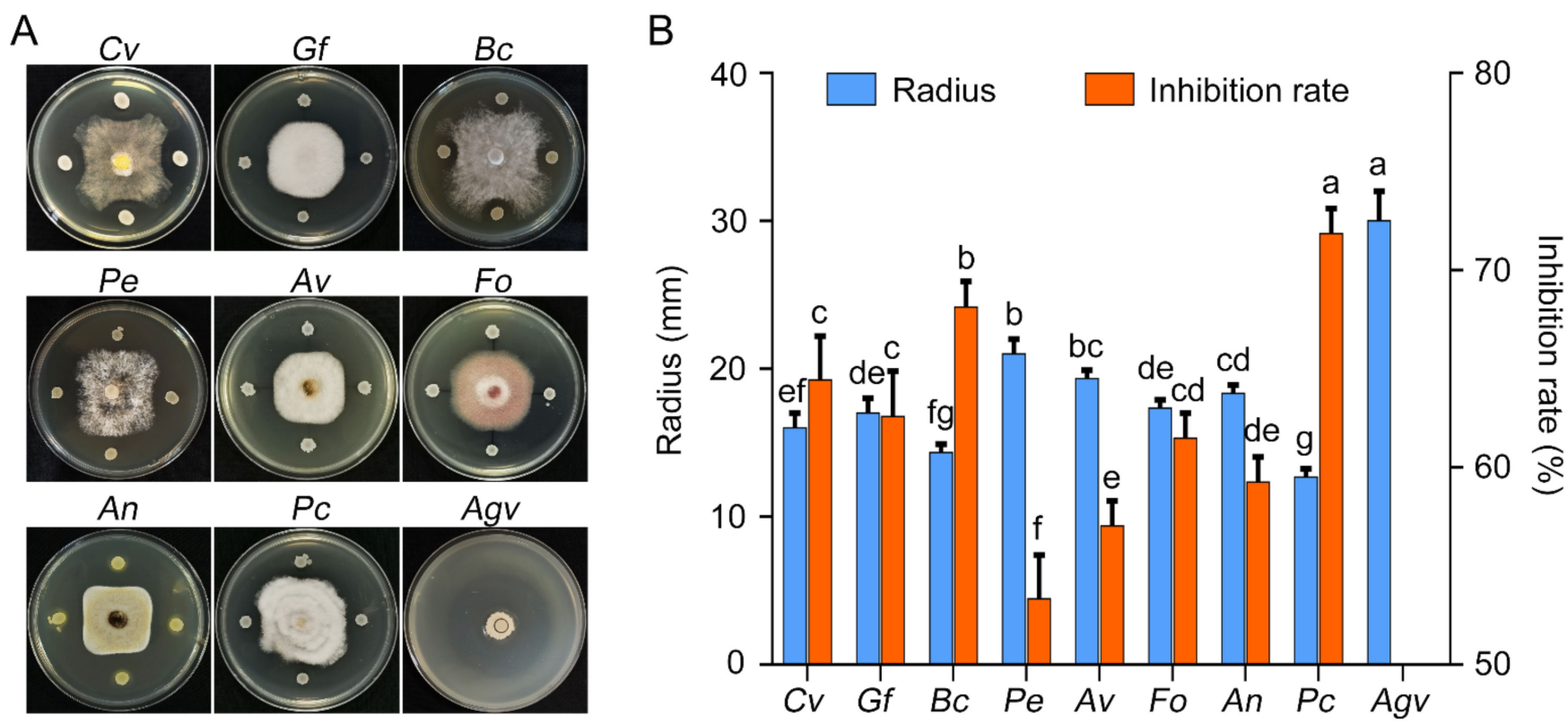

Figure 1. Antagonistic assay of Bacillus velezensis GSBZ09 against eight pathogenic fungi and one pathogenic bacterium. (A) Antagonistic assay of B. velezensis GSBZ09. Coniella vitis (CV). Gloeosporium fructigrum (GF). Botrytis cinerea (BC). Diaporthe eres (Pe). Alternaria viticola (Av). Fusarium oxysporum (Fo). Aspergillus niger (An). Pestalotiopsis clavispora (Pc). Allorhizobium vitis (Agv). (B) Colony radius and inhibition rate of each microorganism. Error bars represents the means \pm standard deviation of three replicate experiments. Different letters above the bars indicate a significant difference at $p<0.05$ according to Duncan's multiple-range test.

\subsection{GSBZ09 Was Identified as Bacillus velezensis}

GSBZ09 was determined to be a Gram-positive, endospore-forming, and aerobic bacterium belonging to the Bacillus family. The strain grew well on lysogeny broth (LB) plates at $28{ }^{\circ} \mathrm{C}$ and produced creamy white colonies with irregular margins after $48 \mathrm{~h}$ of incubation, and they showed a colony morphology and culture characteristics similar to those of other Bacillus strains (Figure 2A). Strain GSBZ09 displayed rod-shaped cells with a length of 3-5 $\mu \mathrm{m}$ and a diameter of $0.8-1.2 \mu \mathrm{m}$ (Figure 2B,C). The strain could grow in $2.0-6.5 \% \mathrm{NaCl}$ and over a wide temperature range $\left(15-80^{\circ} \mathrm{C}\right)$, and the optimal $\mathrm{pH}$ was 7.0. GSBZ09 showed an exponential growth stage from $4 \mathrm{~h}$ post-inoculation (hpi) to $24 \mathrm{hpi}$. Importantly, we also observed that the $\mathrm{pH}$ value increased to 8.18 from an initial value of 7.0 during the culture time (Figure 2D). Biolog assays showed that strain GSBZ09 could utilize diverse carbon sources (Table S1). To understand the genetic relationships between strain GSBZ09 and other Bacillus strains, a phylogenetic tree was constructed based on six housekeeping genes (16S rRNA, rpoD, pgk, gyrB, atpD, and rho) (Table S2). As expected, four primary monophyletic clades, Paenibacillus sp. B. subtilis, B. amyloliquefaciens, and $B$. velezensis, were corroborated by bootstrap values. The phylogenetic tree showed that strain GSBZ09 was closest to B. velezensis FZB42. Based on these data, GSBZ09 belongs to B. velezensis (Figure 2E).

\subsection{Detection of Extracellular Enzyme Production and Growth-Promoting Traits of Strain GSBZ09}

The potential of strain GSBZ09 to antagonize fungi and promote plant growth was evaluated by characterizing several indicators on the plates. Extracellular enzyme assays showed that strain GSBZ09 produced cellulase, protease, amylase and lipase, thus indicating antagonistic traits against fungi. GSBZ09 also has the potential to decompose inorganic phosphorus to fix nitrogen. This strain can produce IAA and siderophores, which indicate its high potential as a competitive strain for biological control (Figure 3). 
A

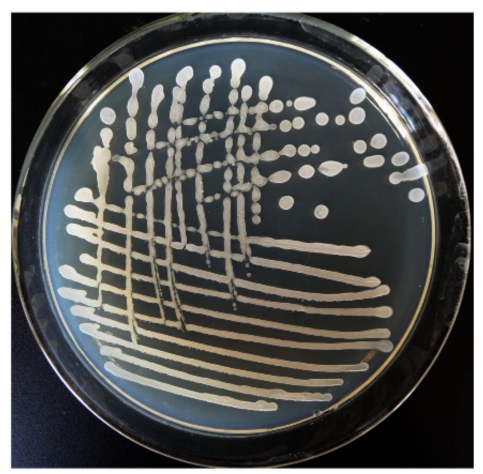

$\mathrm{D}$

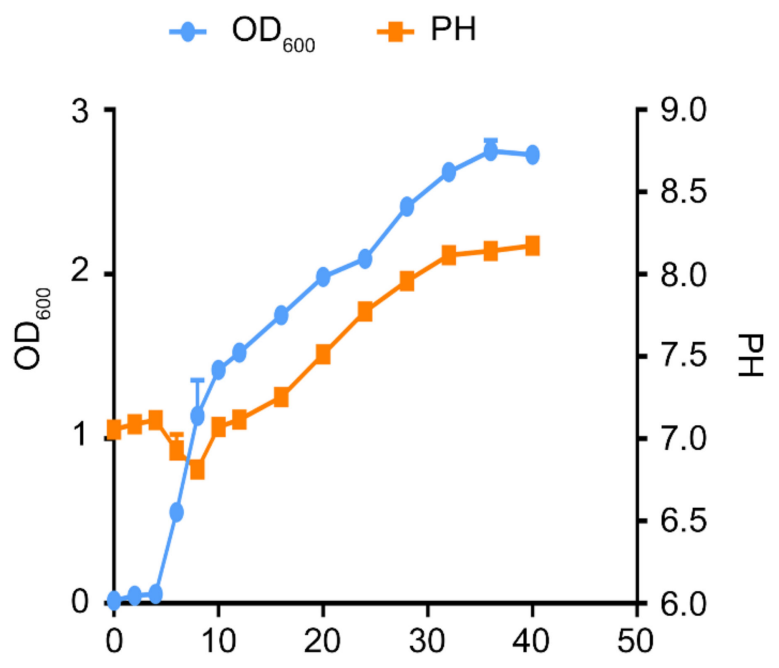

(h)
B

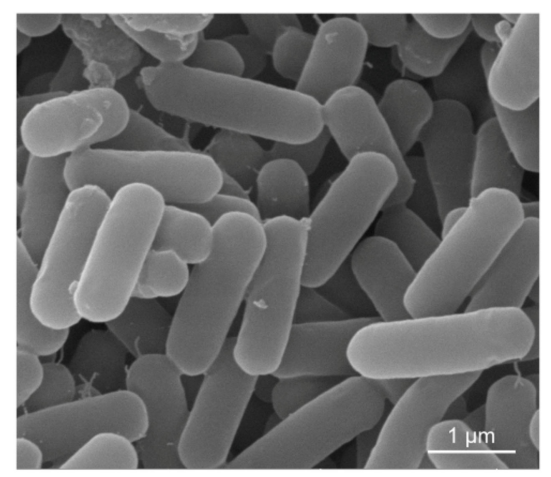

E
C

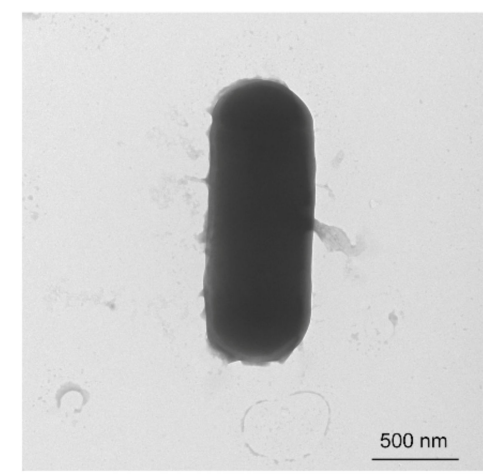

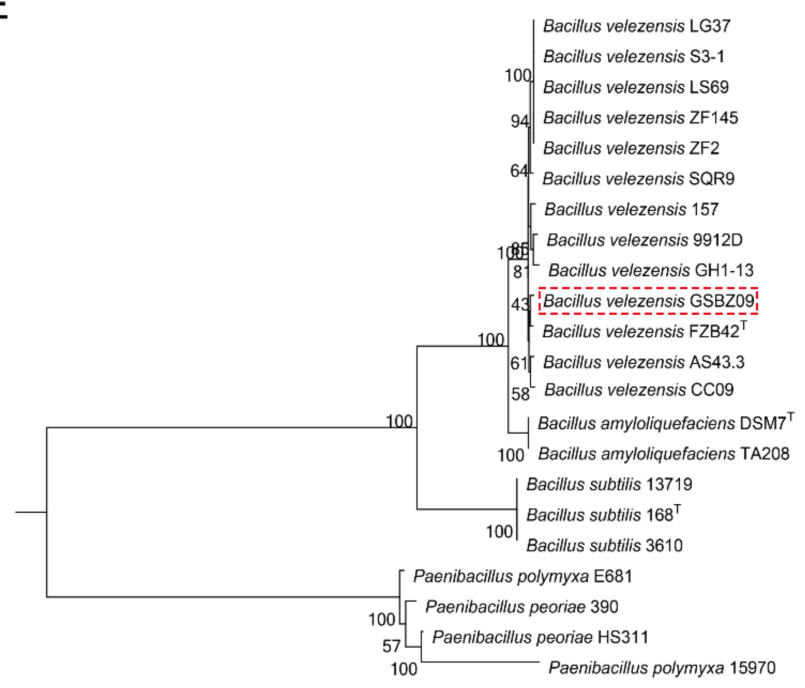

Figure 2. General characteristics of Bacillus velezensis GSBZ09. (A) Image of GSBZ09 colony morphology. Image of GSBZ09 cells using scanning electron microscopy (B) and transmission electron microscopy (C). (D) Phylogenetic tree of B. velezensis GSBZ09 among other Bacillus species. The phylogenetic tree was constructed based on six housekeeping genes (16S rRNA, gyrB, rpoD, atpD, rho, and $p g k$ ) according to the aligned gene sequences using the maximum likelihood method in MEGA 6.0. Bootstrap values (1000 replicates) are shown at the branch points. The scale bar indicates $0.05 \mathrm{nu}-$ cleotide substitutions per nucleotide position. (E) Growth dynamics and $\mathrm{pH}$ change of $B$. velezensis GSBZ09. Error bars represents the means \pm standard deviation of three replicate experiments.

\subsection{Antibiotic Resistance and Hemolysis Assay}

The minimum inhibitory concentration (MIC) is defined as the lowest concentration of antimicrobial agent that inhibits the growth of a microorganism, and the minimum bactericidal concentration $(\mathrm{MBC})$ is the lowest concentration of disinfectant lethal to the bacterium. In this study, strain GSBZ09 exhibited resistance to spectinomycin and showed a MIC of spectinomycin of $216 \mu \mathrm{g} / \mathrm{mL}$ and MBC of $1024 \mu \mathrm{g} / \mathrm{mL}$ (Figure 4). For spectinomycin, strain GSBZ09 showed no tolerance to the antibiotic $(\mathrm{MBC} / \mathrm{MIC}=4.74)$. A blood agar hemolysis assay confirmed that strain GSBZ09 was unable to produce hemolysin activity on plates (Figure S3).

\subsection{GSBZ09 Has High Biocontrol Efficiency on Grape White Rots Caused by C. vitis}

The biocontrol efficacy of strain GSBZ09 against $C$. vitis was evaluated using the leaves and fruit of $V$. vinifera cv. Red Globe (RG). The leaves and fruits of RG inoculated with only C. vitis were used as a positive control, and lesions on the leaves and fruits were observed at $3 \mathrm{dpi}$ (days post-inoculation), with an incidence (disease index) of $72.73 \%(28.95)$ and 
90\% (82.96) in the fruit and leaves, respectively. The negative control (LB medium, GSBZ09 culture, and culture filtrate) exhibited no lesions on the leaves or fruits. To analyze the effect of GSBZ09 on preventing and controlling grape white rot, two treatments were conducted. One treatment consisted of grape inoculation with GSBZ09 $24 \mathrm{~h}$ before inoculation with $C$. vitis to determine the preventive effect, and the other was inoculation with GSBZ09 $24 \mathrm{~h}$ after inoculation with $C$. vitis to determine the control effect. The results showed that the control efficiency of the GSBZ09 culture (culture filtrate) in preventing the disease was better than that of the control, and the GSBZ09 culture exhibited higher biological control efficacy than culture filtrate (Figure 5). For the prevention treatment, the incidence and disease index of fruits treated with the culture (culture filtrate) decreased by $56.94 \%(52.73 \%)$ and $26.03 \%$ (23.02), respectively, while the incidence and disease index of leaves treated with the culture (culture filtrate) decreased by $63.33 \%(53.33 \%)$ and $78.51 \%$ (70.37), respectively.

A
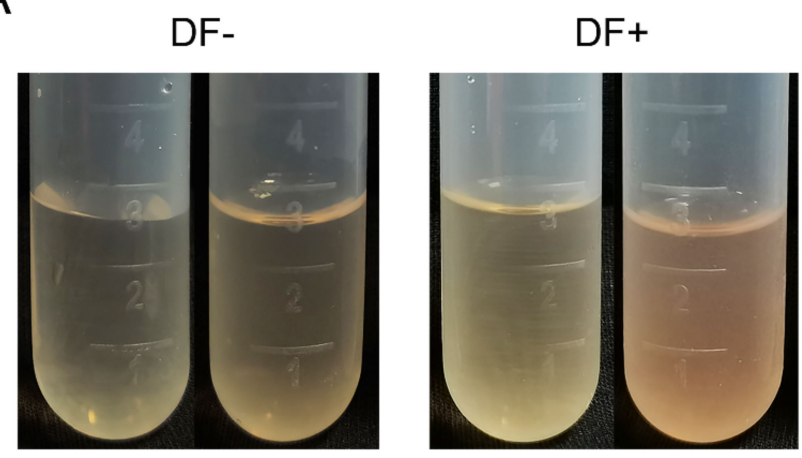

C
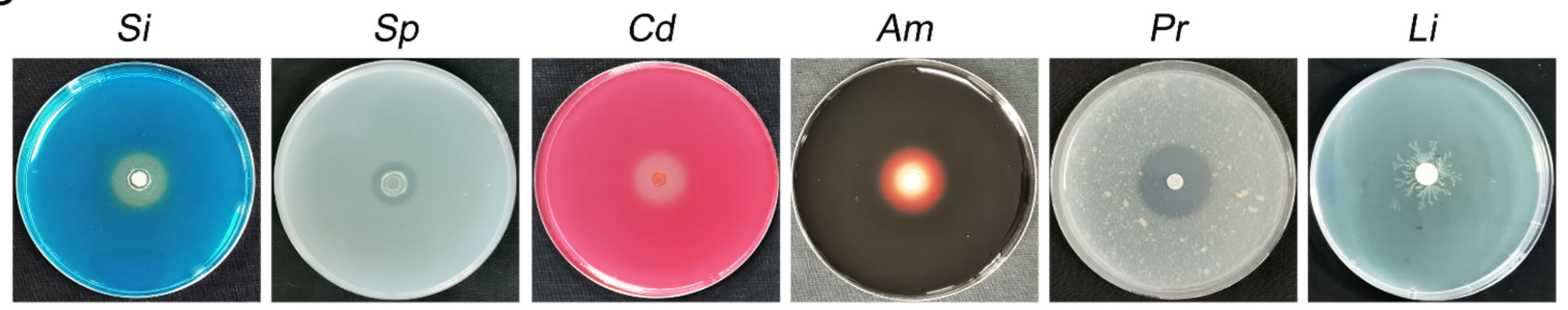

D

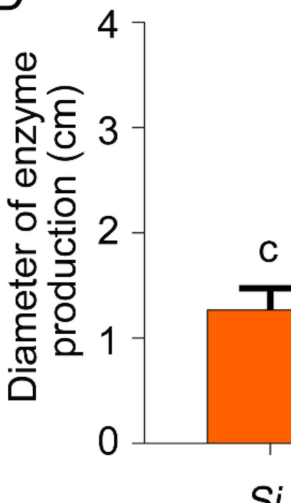

Si
B

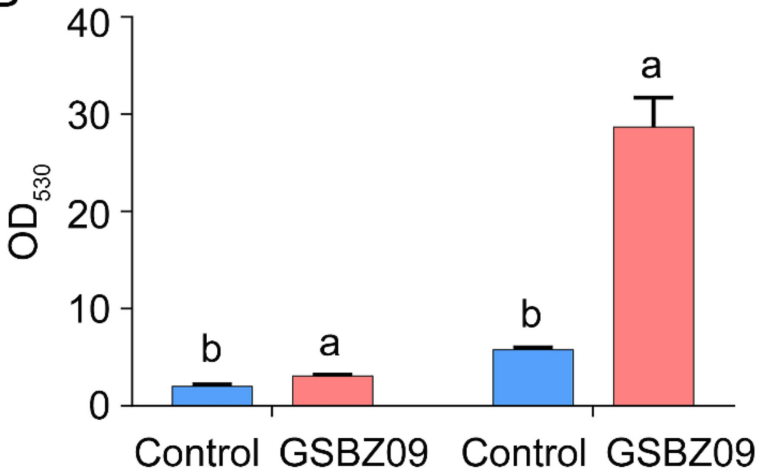


A

CK Spe Amp Van Kan Str Gen Chl Tet Rif

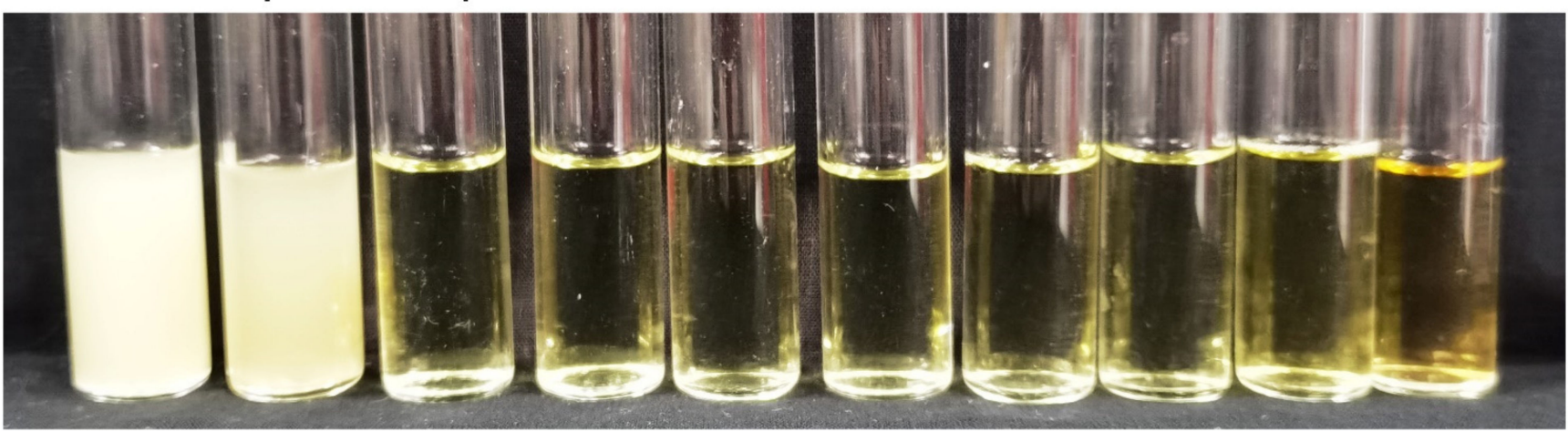

B

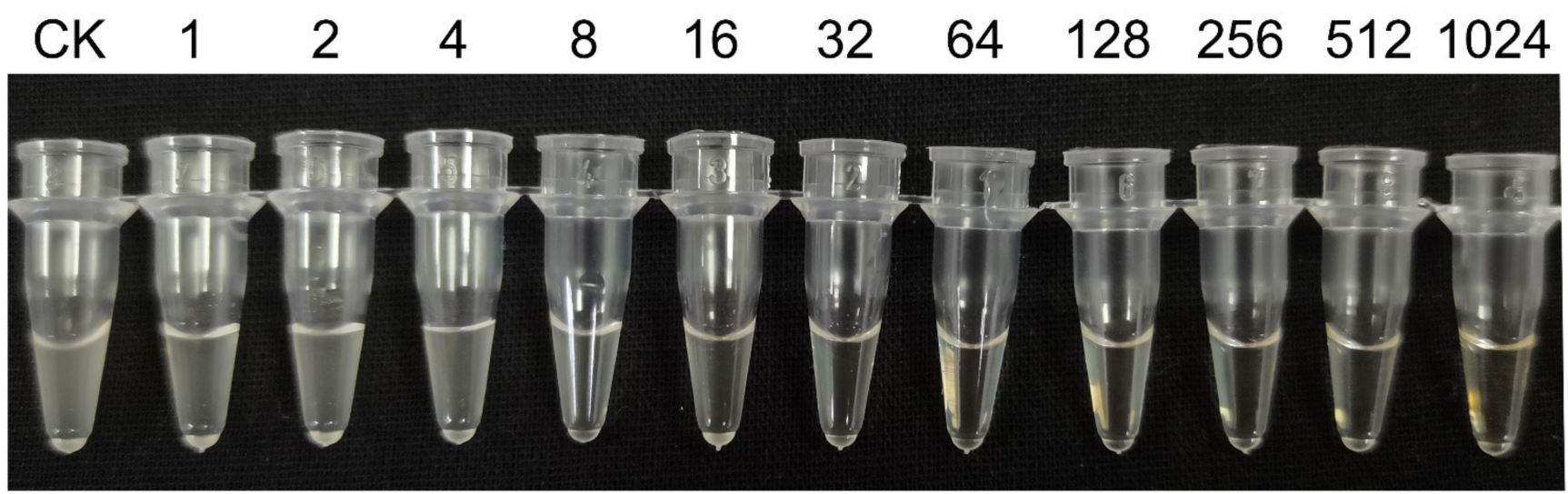

C
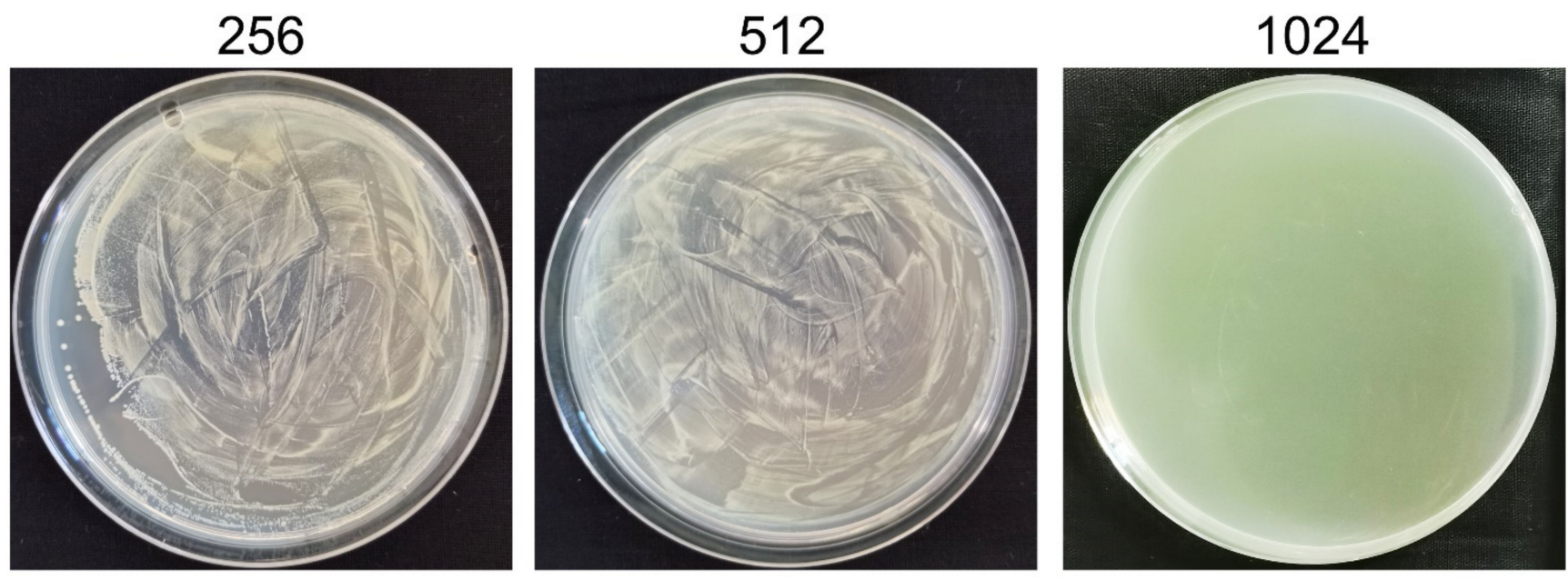

$(\mu \mathrm{g} / \mathrm{mL})$

Figure 4. Determination of antibiotic resistance of Bacillus. velezensis GSBZ09. (A) Survival of B. velezensis GSBZ09 treated with different antibiotics. Spectinomycin (Spe), ampicillin (Amp), vancomycin (Van), kanamycin (Kan), streptomycin (Str), gentamycin (Gen), chloramphenicol (Chl), tetracycline (Tet) and rifampicin (Rif). (B) Minimum inhibitory concentration (MIC) of spectinomycin for strain GSBZ09. (C) Minimum bactericidal concentration (MBC) of spectinomycin for strain GSBZ09. 


\subsection{Effects of GSBZ09 and the Culture Filtrate on Antioxidant Activity and Plant Growth Promotion}

The activities of three protective enzymes, namely superoxide dismutase (SOD), polyphenol oxidase (PPO) and phenylalanine ammonia (PAL), increased to different degrees after treatment with GSBZ09 culture and culture filtrate. Compared with the control, the activities of the three protective enzymes increased $35.21 \%$ (SOD), $24.15 \%$ (PPO) and $0.62 \%$ (PAL) after irrigation with GSBZ09 culture. Meanwhile, the activities of the three protective enzymes increased by $22.52 \%$ (SOD), $20.70 \%$ (PPO) and $26.84 \%$ (PAL) after irrigation with the culture filtrate (Figure 6). In addition, a significant increase in the activities of the protein and proline levels in the $V$. vinifera leaves of the cv. RG and a decline in malondialdehyde (MDA) in the leaves after irrigation with GSBZ09 culture and culture filtrate. The results of the greenhouse experiment revealed that irrigation with GSBZ09 culture and culture filtrate significantly promoted the length (weight) of the aboveground parts and roots compared with the negative control. Obvious differences were not observed between the culture and culture filtrate treatments. The rates of growth promotion for the length, fresh weight and dry weight of shoots (roots) were 30.99\% (23.85\%), 98.69\% (17.90\%) and $55.18 \%(30.82 \%)$, respectively (Figure 6).

A

a1

C

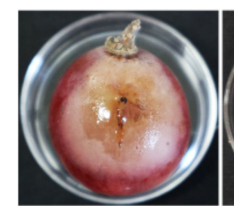

a5
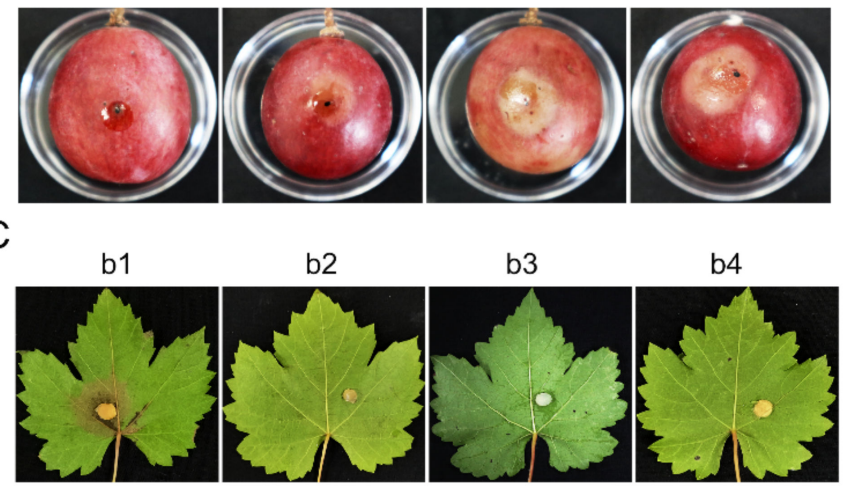

b5

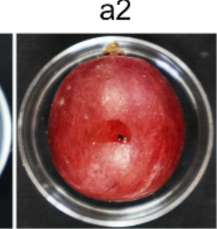

a6

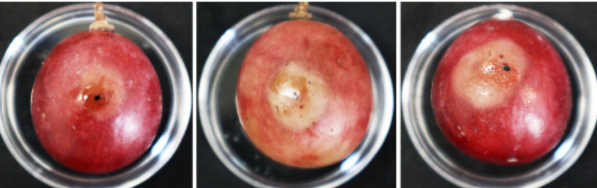

b6

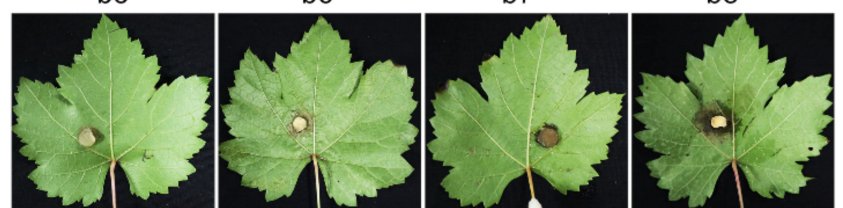

B

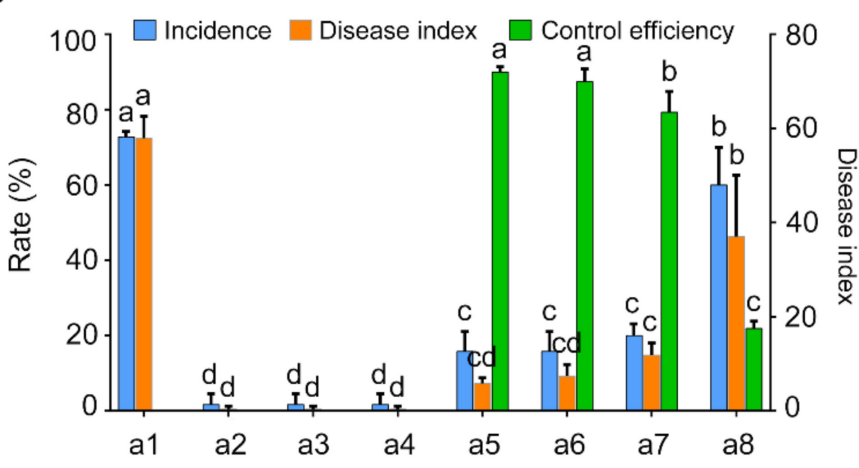

D

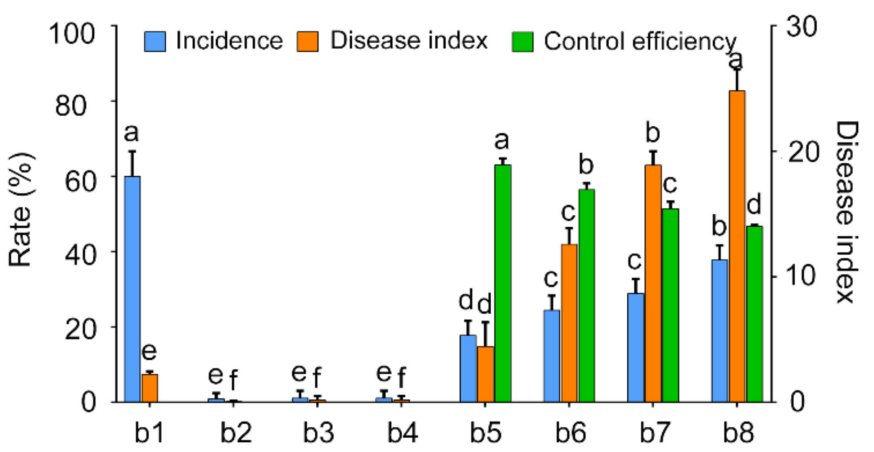

Figure 5. Biocontrol efficiency of Bacillus velezensis GSBZ09 on grape white rot caused by Coniella vitis. (A,C) (a1,b1) Inoculated with C. vitis; (a2,b2) LB broth; (a3,b3) culture of GSBZ09, (a4,b4) culture filtrate of GSBZ09; inoculated with $C$. vitis $24 \mathrm{~h}$ after inoculation with the culture (a5, b5) and culture filtrate $(\mathrm{a} 6, \mathrm{~b} 6)$ of GSBZ09; inoculated culture $(\mathrm{a} 7, \mathrm{~b} 7)$ and culture filtrate $(\mathrm{a} 8, \mathrm{~b} 8)$ of GSBZ09 $24 \mathrm{~h}$ after inoculation with $C$. vitis. (B,D) Incidence, disease index and control efficiency of B. velezensis GSBZ09. Error bars represent the means \pm standard deviation. Ten biological replicates were performed for each treatment, and the experiments were independently repeated three times. Different letters above the bars indicate a significant difference at $p<0.05$ according to Duncan's multi-range test. 
A
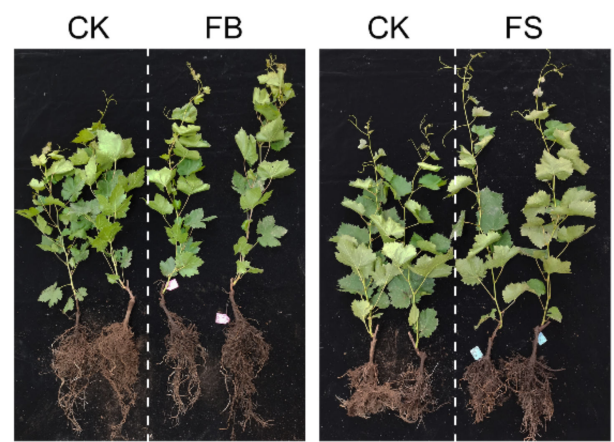

B

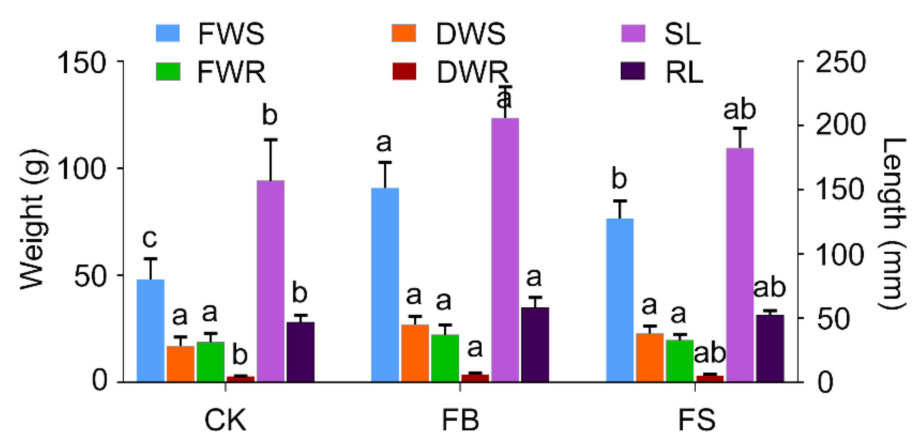

C
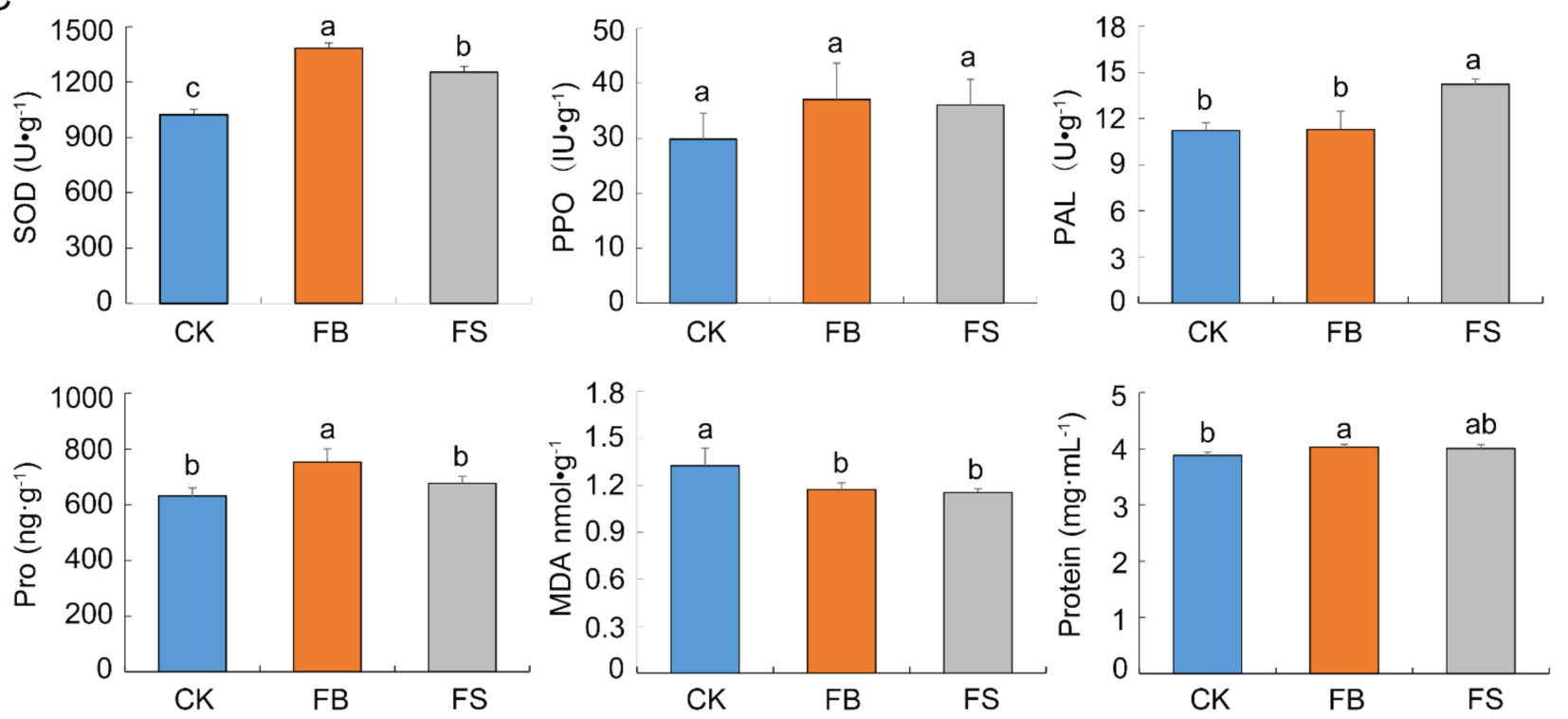

Figure 6. Growth-promoting effect of B. velezensis GSBZ09 on grape. (A) Aspect of grape treatment with LB broth (CK) culture (FB) and culture filtrate (FS) of GSBZ09. (B) Fresh weight of shoots (FWS), dry weight of shoots (DWS), fresh weight of roots (FWT), dry weight of roots (DWT), shoot length (SL), and root length (RL) of grapes. (C) Superoxide dismutase (SOD), polyphenol oxidase (PPO) and phenylalanine ammonia (PAL) enzyme activities in the leaves; malondialdehyde (MDA), protein (Protein) and proline (Pro) of the leaves. Error bars represents the means \pm standard deviation of five replicate experiments. Different letters above the bars indicate a significant difference at $p<0.05$ according to Duncan's multi-range test.

\section{Discussion}

Grape white rot caused by $C$. vitis has been reported as one of the main grape fungal diseases in China and results in an annual production loss of 16.3\% [2]. To date, few studies have focused on the biocontrol of grape white rot disease. Bacillus spp. exhibit broad-spectrum biological activities against various phytopathogens $[7,27]$, and $B$. velezensis has been reported to have good antifungal activity against fungal pathogens on grapes, such as B. cinerea, C. gloeosporioides and P. viticola $[25,28]$. In this study, nine antagonistic Bacillus isolates out of 50 rhizobacterial isolates were screened with $C$. vitis as targets. The nine antagonistic bacterial isolates exerted various levels of activity against $C$. vitis, and $B$. velezensis GSBZ09 showed the strongest antagonistic activity, with wide-spectrum biological activities against G. fructigrum, B. cinerea, D. eres, A. viticola, F. oxysporum, A. niger, and P. clavispora. Furthermore, the culture filtrate of GSBZ09 can also inhibit the mycelial growth of $C$. vitis.

Many PGPR have been reported to enhance plant growth through a wide variety of mechanisms. IAA is an important phytohormone that controls cell enlargement and tissue 
differentiation in plants, and many PGPR bacteria, including Bacillus, Pseudomonas, Agrobacterium, Klebsiella and Rhizobium, can produce IAA to stimulate the growth of plants [7]. B. thuringiensis RZ2MS9 was reported to promote tomato growth by the production of IAA [29]. In our study, a high IAA biosynthetic capacity $(25.56 \mu \mathrm{g} / \mathrm{mL})$ was exhibited in strain GSBZ09, and the pot experiment also demonstrated its effect on plant growth promotion. Phosphate is an essential and necessary element for plant growth and development, and mineral or organic forms of phosphorous are mainly found in soil; however, both forms are unavailable to plants [30]. GSBZ09 has been shown to be a phosphate-solubilizing bacterium that contributes to the utilization of $\mathrm{P}$ from the soil by plants. Siderophores have an exceptionally high affinity for $\mathrm{Fe}^{3+}$ and are able to bind Fe-siderophore complexes, thus promoting Fe uptake by microorganisms, while complexes can also be used by plants to increase the iron content inside plant tissues and improve plant growth [31]. In this study, GSBZ09 was observed to have a higher ability to produce siderophores. Overall, our results suggested the potential of GSBZ09 for improving plant growth.

Antibiotic resistance was established with secular evolution, which contributes to strong environmental adaptability [32]. Tolerance is defined as the inhibition of bacterial growth without lysis, with MBC values at least 32-times the MIC values $[33,34]$. The strain B. velezensis GSBZ09 exhibited resistance to spectinomycin but not resistance to ampicillin, vancomycin, kanamycin, streptomycin, gentamicin, chloramphenicol, tetracycline, or rifampin in our research. For spectinomycin, GSBZ09 showed no tolerance to the antibiotic $(\mathrm{MBC} / \mathrm{MIC}=4.74)$. Moreover, to use $B$. velezensis strains as effective biocontrol agent, they must be safe for animals, humans and the environment; however, the hemolysis phenotype is an indicator of toxicity. Previous studies reported that the biocontrol agents B. cereus and Rahnella aquatilis ZF7 showed hemolysin activity on plates [35]. Compared to B. cereus and $R$. aquatilis ZF7, B. velezensis GSBZ09 was unable to produce hemolysin activity, which indicated that it is friendlier to biological systems.

The biocontrol of plant pathogens by Bacillus occurs with the production of fungal cell wall-degrading enzymes, which is an important mechanism for inhibiting pathogens. B. velezensis ZF2 has been reported to produce protease (Prt) and cellulase (Cel), which may inhibit the mycelial growth of C. cassiicola and suppress cucumber leaf spot disease [9]. The current study demonstrated that B. amyloliquefaciens strain XZ34-1, as a biocontrol agent for the control of Bipolaris sorokiniana, has the ability to produce protease and pectinase [36]. In our study, GSBZ09 produced cellulase, protease, amylase and lipase, which may have resulted in the observed morphological changes and growth inhibition of $C$. vitis hyphae. Additionally, GSBZ09 culture and culture filtrate exhibited very good prevention and control effects on grape white rot caused by $C$. vitis. Biotropic bacteria induce systemic acquired resistance (SAR) in plants, which provides enhanced resistance to incoming pathogens $[37,38]$. Changes in defense enzymes (PAL, PPO, SOD and CAT) are usually used as important indicators to measure the defense response in plants [39]. MDA can affect plant growth and development by damaging the cell membrane [40]. In our study, the MDA content was reduced, suggesting less cell damage. The content of defense enzymes and proline increased in grape leaves treated with B. velezensis GSBZ09, which indicated that GSBZ09 increased the resistance of the grape by removing the reactive oxygen clusters. All these features suggested that strain GSBZ09 could be a promising biocontrol agent for grape white rot disease.

\section{Materials and Methods}

\subsection{Isolation of Bacillus Strains and Antagonism Assays}

B. velezensis GSBZ09 was isolated from soil around the roots of a healthy grape plants in vineyards in Jinan city, Shandong Province, China, in July 2018. Ten grams of soil were weighed and added to a triangular flask containing $90 \mathrm{~mL}$ of sterilized saline, followed by a water bath at $80^{\circ} \mathrm{C}$ for $20 \mathrm{~min}, 10,000$-fold dilution, plating on an LB plate ( 5 g yeast extract, $10 \mathrm{~g}$ peptone, $10 \mathrm{~g} \mathrm{NaCl}, 15 \mathrm{~g}$ agar, $1000 \mathrm{~mL}$ distilled water, $\mathrm{pH}$ 7), and incubation at $28^{\circ} \mathrm{C}$ for $24 \mathrm{~h}$. Bacillus-like strains were selected based on the colony morphology, and used 
for further screening of antagonistic bacteria. Bacterial cells were grown in LB medium overnight at $28{ }^{\circ} \mathrm{C}$ and adjusted to an $\mathrm{OD}_{600}$ of 0.8 . The antagonistic activity of Bacillus strains against $C$. vitis GP1 was assessed through plate bioassays as described by Wang [41]. G. fructigrum, B. cinerea, D. eres, A. viticola, F. oxysporum, A. niger, and P. clavispora, which were kept in our library, were used to determine the percentage inhibition of mycelial growth of other fungal pathogens in grapes. The fungal pathogens were cultured on potato dextrose agar (PDA) plates (20 g glucose, $200 \mathrm{~g}$ potato, $15 \mathrm{~g}$ agar, $1000 \mathrm{~mL}$ distilled water, $\mathrm{pH}$ 7). Additionally, the antagonistic activity of GSBZ09 against Allorhizobium vitis was determined using the double-layer agar plate method $(15 \mathrm{~mL}$ bottom-layer PDA, $10 \mathrm{~mL}$ toplayer $2 \%$ agar) [42]. The percentage of growth inhibition was calculated by the following equation: $\mathrm{n}=[(\mathrm{A}-\mathrm{B}) / \mathrm{A}] \times 100$, where $\mathrm{A}$ is the colony diameter of control fungi and $\mathrm{B}$ is the colony diameter of treated fungi. The values were recorded as the means of four replicates, and each experiment was repeated three times.

\subsection{Identification of Strain GSBZ09}

\subsubsection{Genomic DNA Extraction and Phylogenetic Analysis}

The strain GSBZ09 was cultured in LB media at $28^{\circ} \mathrm{C}$ with shaking at $200 \mathrm{rpm}$ for $12 \mathrm{~h}$. Genomic DNA was extracted from cultured GSBZ09 cells $\left(\mathrm{OD}_{600}=0.8\right)$ using a TIANamp Bacteria DNA kit (Tiangen Biotech Co., Ltd., Beijing, China). The taxonomic position of strain GSBZ09 was determined by multilocus gene sequence analysis (MLSA) based on six housekeeping genes (16S rRNA, gyrB, rpoD, atpD, rho and $p g k$ ). The phylogenetic tree was constructed using the maximum likelihood method in MEGA 6.0. Other available gene sequences of closely related species for phylogenetic tree construction were downloaded from the NCBI database (Table S2).

\subsubsection{Morphological, Physiological and Biochemical Tests}

Strain GSBZ09 was cultured on LB medium plates and incubated at $28{ }^{\circ} \mathrm{C}$ for $24 \mathrm{~h}$ to observe the colony characteristics, such as the color, morphology and growth properties. The strain morphologies were observed by scanning electron microscopy (SEM) and transmission electron microscopy (TEM 1230 microscope, JEOL) [43]. Physiological and biochemical tests were performed using the Biolog GN2 microplate system (Biolog, Haywood, CA, USA) [44]. The growth curve and the dynamic change in $\mathrm{pH}$ were measured every $4 \mathrm{~h}$.

In vitro characterization of strain GSBZ09 was checked for growth at diverse $\mathrm{pH}$, salt concentration and temperature. To check the $\mathrm{pH}$ sensitivity, the strain GBSZ09 was cultured at $28^{\circ} \mathrm{C}$ for $24 \mathrm{~h}$ in tubes containing $5 \mathrm{~mL}$ of $\mathrm{LB}$ medium maintained at $3,5,7,9,11$, $13 \mathrm{pH}$. Similarly, the strain GSBZ09 was grown in LB media tubes containing different salt concentration $(1,2,3.5,5,6.5,8 \%$, ) to observe its sensitivity to salt. For temperature tests, the GBSZ09 was cultured in LB media tubes, which incubated at different temperature $\left(10,30,50,70,80,90,100{ }^{\circ} \mathrm{C}\right)$.

\subsection{Measurement of Extracellular Enzyme Production}

\subsubsection{Protease Production}

Skim milk agar plates (skim milk, $100 \mathrm{~g}$; peptone, 5 g; agar, $15 \mathrm{~g}$; distilled water, $1000 \mathrm{~mL}$ ) were prepared to detect Protease production. B. velezensis GSBZ09 overnight at $28^{\circ} \mathrm{C}$ with shaking at $200 \mathrm{rpm}$, then $2 \mu \mathrm{L}$ of GSBZ09 culture $\left(\mathrm{OD}_{600}=0.8\right)$ was inoculated onto the center of skim milk agar plates. After $48 \mathrm{~h}$ of incubation at $28^{\circ} \mathrm{C}$, protease activity was observed based on the presence of clear zones around bacterial cultures.

\subsubsection{Cellulose Degradation}

The cellulose-degrading ability of $B$. velezensis GSBZ09 $\left(\mathrm{OD}_{600}=0.8\right)$ was determined by the medium (carboxymethyl cellulose (CMC, 1 g; $\mathrm{Na}_{3} \mathrm{PO}_{4}, 25 \mathrm{mmol}$; pH 7.0; agar, 20 g; and distilled water, $1000 \mathrm{~mL}$ ) [41]. After incubation at $28^{\circ} \mathrm{C}$ for $5 \mathrm{~d}$, the plates were rinsed for $15 \mathrm{~min}$ with a $1 \%$ solution of Congo red dye and then washed twice with $1 \mathrm{M} \mathrm{NaCl}$ 
buffer. The diameter of the clear zone around the colony (cellulose degradation) was measured [45].

\subsubsection{Amylase Production}

The ability of B. velezensis GSBZ09 to produce amylase was determined in medium containing soluble starch $5 \mathrm{~g} / \mathrm{L}, \mathrm{NaCl} 5 \mathrm{~g} / \mathrm{L}$, and agar $20 \mathrm{~g} / \mathrm{L}$ (Lugol solution; MERCK). After $48 \mathrm{~h}$ of incubation at $28^{\circ} \mathrm{C}$, the plates were stained with an iodine solution.

\subsubsection{Lipase Production}

Selective medium containing $10 \mathrm{~g}$ of peptone, $0.1 \mathrm{~g}$ of $\mathrm{CaCl}_{2}, 2.5 \mathrm{~g}$ of $\mathrm{NaCl}, 10 \mathrm{~mL}$ of Tween 20, and $15 \mathrm{~g}$ of agar was used to determine the ability of B. velezensis GSBZ09 to produce lipase. The bacteria were streaked on the medium and incubated at $28^{\circ} \mathrm{C}$ for $72 \mathrm{~h}$. Lipase activity was determined based on the presence of depositions around bacterial colonies [46].

\subsection{Measurement of IAA Production, Siderophores and Mineral Phosphate Solubilization}

Strain GSBZ09 was cultured in DF (peptone, 5.0 g; yeast extract, $1.5 \mathrm{~g}$; beef extract, $1.5 \mathrm{~g} / \mathrm{L} ; \mathrm{NaCl}, 5.0 \mathrm{~g} / \mathrm{L}$; tryptophan, $0.5 \mathrm{~g} / \mathrm{L}$ ) salt minimal medium, and L-tryptophan was added to the medium to a concentration of $1.02 \mathrm{~g} / \mathrm{L}$ [47]. After incubation for $24 \mathrm{~h}$ at $28{ }^{\circ} \mathrm{C}$, the IAA concentration was estimated according to the method described by Yuan et al. (2011) [48]. National Botanical Research Institute Phosphate (NBRIP) solid medium was used to determine the capability of strain GSBZ09 to solubilize phosphate [49]. Ten microliters of bacterial culture were dropped on sterile filter paper (diameter, $5 \mathrm{~mm}$ ) and placed in the middle of agar plates containing NBRIP. The clear zone around the colony was measured after $7 \mathrm{~d}$ at $28^{\circ} \mathrm{C}$ [50]. A CAS agar plate was used for qualitative analysis of siderophores, and yellow circles that appeared around the colonies were measured after $7 \mathrm{~d}$ of incubation at $28^{\circ} \mathrm{C}$ [51].

\subsection{Antibiotic Resistance and Hemolysis Assay}

Nine antibiotics, spectinomycin $(50 \mu \mathrm{g} / \mathrm{mL})$, ampicillin $(200 \mu \mathrm{g} / \mathrm{mL})$, vancomycin $(50 \mu \mathrm{g} / \mathrm{mL})$, kanamycin $(50 \mu \mathrm{g} / \mathrm{mL})$, streptomycin $(10 \mu \mathrm{g} / \mathrm{mL})$, gentamycin $(10 \mu \mathrm{g} / \mathrm{mL})$, chloramphenicol $(20 \mu \mathrm{g} / \mathrm{mL})$, tetracycline $(5 \mu \mathrm{g} / \mathrm{mL})$ and rifampicin $(10 \mu \mathrm{g} / \mathrm{mL})$, were used to test the characteristics of the antibiotic resistance of GSBZ09. The MIC and MBC of ampicillin for strain GSBZ09 were determined as previously described [52].

The strain GSBZ09 was cultured in LB media at $28{ }^{\circ} \mathrm{C}$ with shaking at $200 \mathrm{rpm}$ for $12 \mathrm{~h}$, and $5 \mu \mathrm{L}$ of bacterial culture was dropped on Wagstsuma Blood Agar Base (Hopebio, Qingdao, China) and then cultured at $28^{\circ} \mathrm{C}$. Hemolysis was determined by observation of a cleared zone surrounding bacteria grown on the plates [53].

\subsection{Assessment of Biocontrol Activity and Plant Growth Promotion}

To evaluate the plant growth promotion activity, five young 1-year-old plants of $V$. vinifera $\mathrm{cv}$. RG were selected for treatment with $50 \mathrm{~mL}$ of GSBZ09 culture $\left(10^{8} \mathrm{CFU} / \mathrm{mL}\right)$ and culture filtrate by irrigation, irrigation treatment were conducted weekly during a month. Additionally, another five plants used as controls were treated with sterile water. The weight of the root and shoot of $\mathrm{cv}$. RG were measured $60 \mathrm{~d}$ after the irrigation. The SOD, PPO and PAL enzyme activities in the leaves were detected by previously described methods [54]. In addition, the MDA, protein and proline contents of the leaves were measured using previously published methods [55-57].

The pathogenic strain $C$. vitis GP1 of grape white rot was grown on PDA plates for $3 \mathrm{~d}$ at $28{ }^{\circ} \mathrm{C}$. The strain was used to inoculate $V$. vinifera $\mathrm{cv}$. RG by detached leaves and fruit inoculation. Surface sterilization of the leaves and fruits was performed as previously described [3]. PDA plugs $(8 \mathrm{~mm})$ with fungi were inoculated on the leaves, and fruit were inoculated with $20 \mu \mathrm{L}$ of spore suspension $\left(1 \times 10^{7}\right.$ spores $\left./ \mathrm{mL}\right)$. For the control, we used PDA plugs without fungi and sterilized water. One day after inoculation, the GSBZ09 
cultures at a concentration of $10^{8} \mathrm{CFU} / \mathrm{mL}$ were sprayed to test their ability to control grape white rot. GSBZ09 cultures sprayed before inoculation of the pathogenic strain C. vitis GP1 were used to test the prevention effect. All the leaves and fruit were maintained at $28{ }^{\circ} \mathrm{C}$ and $80 \%$ to $90 \%$ RH. The incidence, lesion diameter of the leaves, disease index of the fruit, and control efficiency of the GSBZ09 cultures and the culture filtrate were recorded $5 \mathrm{~d}$ after inoculation.

\subsection{Statistical Analysis}

The data were analyzed based on an ANOVA and Duncan's multiple range test ( $p \leq 0.05)$ using the statistical software SPSS version 19.0 (SPSS Inc., Chicago, IL, USA). The significance between the means of different treatments was evaluated using Duncan's (D) test.

\section{Conclusions}

B. velezensis GSBZ09 isolated from grapevine had a broad range of antagonistic activities against many fungal and bacterial pathogens on grape. Furthermore, GSBZ09 showed a variety of beneficial features, including IAA production, phosphate solubilization and siderophores, thus revealing its beneficial features related to plant growth promotion. Further study showed that B. velezensis GSBZ09 could produce cellulase, protease, amylase and lipase and improve the level of defense-related antioxidant enzymes in grape. Additionally, GSBZ09 culture and culture filtrate exhibited significant biological control efficacy on grape write rot. All these features indicated that strain GSBZ09 could be a promising biocontrol agent for grape disease control and could promote the practical application of strain GSBZ09.

Supplementary Materials: The following supporting information can be downloaded at: https: / / www.mdpi.com/article/10.3390/pathogens11020248/s1, Figure S1. Nine antifungal activities of different Bacillus strains against Coniella vitis. (A) Antifungal activity of nine Bacillus strains against $C$. vitis. (B) Colony radius and inhibition rate of each strain. Error bars represents the means \pm standard deviation of three replicate experiments. Different letters above the bars indicate a significant difference at $p<0.05$ according to Duncan's multi-range test. Figure S2. Antagonistic assay of Bacillus velezensis GSBZ09 culture filtrate. (A) Coniella vitis. (B) C. vitis cultured on PDA with $20 \%$ GSBZ09 culture filtrate. (C) C. vitis cultured on PDA with 1\% GSBZ09 culture filtrate. (D) Spore germination of $C$. vitis on $1 \%$ glucose solution. (E) Spore germination of $C$. vitis on $1 \%$ glucose solution and 10\% GSBZ09 culture filtrate. (F) Mycelia on a PDA plate. (G) Mycelia on the antagonistic plate. Figure S3. Hemolysis assay of GSBZ09. Table S1. Biolog assays of Bacillus velezensis GSBZ09. Table S2. Information on the strains and six housekeeping genes used for phylogenetic tree contruction in this study.

Author Contributions: X.Y., L.Y. and Y.W. conceived and designed the experiments. X.Y., L.Y., T.L., X.J., X.T. and J.Z. performed the experiments and analyzed the data. X.Y., L.Y. and T.L. wrote the manuscript. All authors have read and agreed to the published version of the manuscript.

Funding: This research was jointly supported by the Natural Science Foundation of Shandong Province, China (Grant No. ZR2021QC131) and Guide Fund of Shandong Academy of Grape (Grant No. SDAG2021B10; SDAG2021B06; SDAG2021B02).

Institutional Review Board Statement: Not applicable.

Informed Consent Statement: Not applicable.

Data Availability Statement: Not applicable.

Conflicts of Interest: The authors declare no conflict of interest. 


\section{References}

1. Ji, T.; Languasco, L.; Li, M.; Rossi, V. Effects of Temperature and Wetness Duration on Infection by Coniella diplodiella, the Fungus Causing White Rot of Grape Berries. Plants 2021, 10, 1696. [CrossRef] [PubMed]

2. Liu, R.; Wang, Y.; Li, P.; Sun, L.; Jiang, J.; Fan, X.; Liu, C.; Zhang, Y. Genome Assembly and Transcriptome Analysis of the Fungus Coniella diplodiella During Infection on Grapevine (Vitis vinifera L.). Front. Microbiol. 2021, 11, 599150. [CrossRef] [PubMed]

3. Chethana, K.W.T.; Zhou, Y.; Zhang, W.; Liu, M.; Xing, Q.K.; Li, X.H.; Yan, J.Y.; Hyde, K.D. Coniella vitis sp. nov. Is the Common Pathogen of White Rot in Chinese Vineyards. Plant Dis. 2017, 101, 2123-2136. [CrossRef] [PubMed]

4. Bisiach, M. White Rot. In Compendium of Grape Disease; Pearson, R.C., Goheen, A.C., Eds.; American Phytopathological Society: St. Paul, MN, USA, 1988; pp. 22-23.

5. He, Z.; Cui, C.; Jiang, J.X. First Report of White Rot of Grape Caused by Pilidiella castaneicola in China. Plant Dis. $2017,101,1673$. [CrossRef]

6. Zhou, S.; Li, B. Genome Sequence Resource of Coniella vitis, a Fungal Pathogen Causing Grape White Rot Disease. Mol. Plant-Microbe Interact. 2020, 33, 787-789. [CrossRef]

7. Vejan, P.; Abdullah, R.; Khadiran, T.; Ismail, S.; Boyce, A.N. Role of Plant Growth Promoting Rhizobacteria in Agricultural Sustainability-A Review. Molecules 2016, 21, 573. [CrossRef]

8. Wang, L.-T.; Lee, F.-L.; Tai, C.-J.; Kuo, H.-P. Bacillus velezensis is a later heterotypic synonym of Bacillus amyloliquefaciens. Int. J. Syst. Evol. Microbiol. 2008, 58, 671-675. [CrossRef]

9. Xu, S.; Xie, X.; Zhao, Y.; Shi, Y.; Chai, A.; Li, L.; Li, B. Whole-genome analysis of Bacillus velezensis ZF2, a biocontrol agent that protects Cucumis Sativus against Corynespora leaf spot diseases. 3 Biotech 2020, 10, 186. [CrossRef]

10. Shao, J.-H.; Li, Y.-C.; Li, Z.-F.; Xu, Z.-H.; Xun, W.-B.; Zhang, N.; Feng, H.-C.; Miao, Y.-Z.; Shen, Q.-R.; Zhang, R.-F. Participating mechanism of a major contributing gene ysnE for auxin biosynthesis in Bacillus amyloliquefaciens SQR9. J. Basic. Microbiol. 2021, 61, 569-575. [CrossRef]

11. Cai, X.-C.; Xi, H.; Liang, L.; Liu, J.-D.; Liu, C.-H.; Xue, Y.-R.; Yu, X.-Y. Rifampicin-Resistance Mutations in the rpoB Gene in Bacillus velezensis CC09 have Pleiotropic Effects. Front. Microbiol. 2017, 8, 178. [CrossRef]

12. Agersø, Y.; Stuer-Lauridsen, B.; Bjerre, K.; Jensen, M.G.; Johansen, E.; Bennedsen, M.; Brockmann, E.; Nielsen, B. Antimicrobial Susceptibility Testing and Tentative Epidemiological Cutoff Values for Five Bacillus Species Relevant for Use as Animal Feed Additives or for Plant Protection. Appl. Environ. Microbiol. 2018, 84, 01108-01118. [CrossRef] [PubMed]

13. Lugtenberg, B.; Kamilova, F. Plant-Growth-Promoting Rhizobacteria. Annu. Rev. Microbiol. 2009, 63, 541-556. [CrossRef] [PubMed]

14. Leveau, J.H.J.; Gerards, S. Discovery of a bacterial gene cluster for catabolism of the plant hormone indole 3-acetic acid. FEMS Microbiol. Ecol. 2008, 65, 238-250. [CrossRef] [PubMed]

15. Spaepen, S.; Vanderleyden, J.; Remans, R. Indole-3-acetic acid in microbial and microorganism-plant signaling. FEMS Microbiol. Rev. 2007, 31, 425-448. [CrossRef]

16. Choub, V.; Ajuna, H.B.; Won, S.-J.; Moon, J.-H.; Choi, S.-I.; Maung, C.E.H.; Kim, C.-W.; Ahn, Y.S. Antifungal Activity of Bacillus velezensis CE 100 against Anthracnose Disease (Colletotrichum gloeosporioides) and Growth Promotion of Walnut (Juglans regia L.) Trees. Int. J. Mol. Sci. 2021, 22, 10438. [CrossRef]

17. Sibponkrung, S.; Kondo, T.; Tanaka, K.; Tittabutr, P.; Boonkerd, N.; Yoshida, K.-I.; Teaumroong, N. Co-Inoculation of Bacillus velezensis Strain S141 and Bradyrhizobium Strains Promotes Nodule Growth and Nitrogen Fixation. Microorganisms 2020, 8, 678. [CrossRef]

18. Pajčin, I.; Vlajkov, V.; Frohme, M.; Grebinyk, S.; Grahovac, M.; Mojićević, M.; Grahovac, J. Pepper Bacterial Spot Control by Bacillus velezensis: Bioprocess Solution. Microorganism 2020, 8, 1463. [CrossRef]

19. Khalid, F.; Khalid, A.; Fu, Y.; Hu, Q.; Zheng, Y.; Khan, S.; Wang, Z. Potential of Bacillus velezensis as a probiotic in animal feed: A review. J. Microbiol. 2021, 59, 627-633. [CrossRef]

20. Zeng, Q.; Xie, J.; Li, Y.; Gao, T.; Zhang, X.; Wang, Q. Comprehensive Genomic Analysis of the Endophytic Bacillus altitudinis Strain GLB197, a Potential Biocontrol Agent of Grape Downy Mildew. Front. Genet. 2021, 12, 729603. [CrossRef]

21. Zeng, Q.; Xie, J.; Zhang, X.; Li, Y.; Wang, Q. Complete genome sequence data of Bacillus pumilus GLB197, an effective antagonist of grape downy mildew. Data Brief 2020, 30, 105423. [CrossRef]

22. Aoki, T.; Aoki, Y.; Ishiai, S.; Otoguro, M.; Suzuki, S. Impact of Bacillus cereus NRKT on grape ripe rot disease through resveratrol synthesis in berry skin. Pest Manag. Sci. 2017, 73, 174-180. [CrossRef] [PubMed]

23. Ruiz-García, C.; Béjar, V.; Martínez-Checa, F.; Llamas, I.; Quesada, E. Bacillus velezensis sp. nov., a surfactant-producing bacterium isolated from the river Vélez in Málaga, southern Spain. Int. J. Syst. Evol. Microbiol. 2005, 55, 191-195. [CrossRef] [PubMed]

24. Chen, L.; Gu, W.; Xu, H.-Y.; Yang, G.-L.; Shan, X.-F.; Chen, G.; Wang, C.-F.; Qian, A.-D. Complete genome sequence of Bacillus velezensis 157 isolated from Eucommia ulmoides with pathogenic bacteria inhibiting and lignocellulolytic enzymes production by SSF. 3 Biotech 2018, 8, 114. [CrossRef] [PubMed]

25. Hamaoka, K.; Aoki, Y.; Suzuki, S. Isolation and Characterization of Endophyte Bacillus velezensis KOF112 from Grapevine Shoot Xylem as Biological Control Agent for Fungal Diseases. Plants 2021, 10, 1815. [CrossRef]

26. Nifakos, K.; Tsalgatidou, P.C.; Thomloudi, E.-E.; Skagia, A.; Kotopoulis, D.; Baira, E.; Delis, C.; Papadimitriou, K.; Markellou, E.; Venieraki, A.; et al. Genomic Analysis and Secondary Metabolites Production of the Endophytic Bacillus velezensis Bvel1: A Biocontrol Agent against Botrytis cinerea Causing Bunch Rot in Post-Harvest Table Grapes. Plants 2021, 10, 1716. [CrossRef] 
27. Abbas, A.; Khan, S.U.; Khan, W.U.; Saleh, T.A.; Khan, M.H.U.; Ullah, S.; Ali, A.; Ikram, M. Antagonist effects of strains of Bacillus spp. against Rhizoctonia solani for their protection against several plant diseases: Alternatives to chemical pesticides. Comptes Rendus. Biol. 2019, 342, 124-135. [CrossRef]

28. Toral, L.; Rodríguez, M.; Béjar, V.; Sampedro, I. Antifungal Activity of Lipopeptides from Bacillus XT1 CECT 8661 Against Botrytis cinerea. Front. Microbiol. 2018, 9, 1315. [CrossRef]

29. Batista, B.D.; Dourado, M.N.; Figueredo, E.F.; Hortencio, R.O.; Marques, J.P.R.; Piotto, F.A.; Bonatelli, M.L.; Settles, M.L.; Azevedo, J.L.; Quecine, M.C. The auxin-producing Bacillus thuringiensis RZ2MS9 promotes the growth and modifies the root architecture of tomato (Solanum lycopersicum cv. Micro-Tom). Arch. Microbiol. 2021, 203, 3869-3882. [CrossRef]

30. Saeid, A.; Prochownik, E.; Dobrowolska-Iwanek, J. Phosphorus Solubilization by Bacillus Species. Molecules $2018,23,2897$. [CrossRef]

31. Chuljerm, H.; Deeudom, M.; Fucharoen, S.; Mazzacuva, F.; Hider, R.C.; Srichairatanakool, S.; Cilibrizzi, A. Characterization of two siderophores produced by Bacillus megaterium: A preliminary investigation into their potential as therapeutic agents. Biochim. Biophys. Acta Gen. Subj. 2020, 1864, 129670. [CrossRef]

32. Martinez, J.L. General principles of antibiotic resistance in bacteria. Drug Discov. Today Technol. 2014, 11, 33-39. [CrossRef] [PubMed]

33. Glauser, M.P.; Bernard, J.P.; Moreillon, P.; Francioli, P. Successful Single-Dose Amoxicillin Prophylaxis Against Experimental Streptococcal Endocarditis: Evidence for Two Mechanisms of Protection. J. Infect. Dis. 1983, 147, 568-575. [CrossRef] [PubMed]

34. Huang, C.Y.; Hsieh, S.P.; Kuo, P.A.; Jane, W.N.; Tu, J.; Wang, Y.N.; Ko, C.H. Impact of disinfectant and nutrient concentration on growth and bioflm formation for a Pseudomonas strain and the mixed cultures from a fine papermachine system Int. Biodeter. Biodegr. 2009, 63, 998-1007. [CrossRef]

35. Yuan, L.; Li, L.; Zheng, F.; Shi, Y.; Xie, X.; Chai, A.; Li, B. The complete genome sequence of Rahnella aquatilis ZF7 reveals potential beneficial properties and stress tolerance capabilities. Arch. Microbiol. 2020, 202, 483-499. [CrossRef]

36. Yi, Y.; Shan, Y.; Liu, S.; Yang, Y.; Liu, Y.; Yin, Y.; Hou, Z.; Luan, P.; Li, R. Antagonistic Strain Bacillus amyloliquefaciens XZ34-1 for Controlling Bipolaris sorokiniana and Promoting Growth in Wheat. Pathogens 2021, 10, 1526. [CrossRef]

37. Whipps, J.M. Microbial interactions and biocontrol in the rhizosphere. J. Exp. Bot. 2001, 52, 487-511. [CrossRef]

38. Durrant, W.; Dong, X. Systemic Acquired Resistance. Annu. Rev. Phytopathol. 2004, 42, 185-209. [CrossRef]

39. Kumari, A.; Goyal, M.; Mittal, A.; Kumar, R. Defensive capabilities of contrasting sorghum genotypes against Atherigona soccata (Rondani) infestation. Protoplasma 2021, 1-14. [CrossRef]

40. Masmoudi, F.; Tounsi, S.; Dunlap, C.A.; Trigui, M. Halotolerant Bacillus spizizenii FMH45 promoting growth, physiological, and antioxidant parameters of tomato plants exposed to salt stress. Plant Cell Rep. 2021, 40, 1199-1213. [CrossRef]

41. Wang, J.; Tavakoli, J.; Tang, Y. Bacterial cellulose production, properties and applications with different culture methods-A review. Carbohydr. Polym. 2019, 219, 63-76. [CrossRef]

42. Jaschke, P.R.; Dotson, G.A.; Hung, K.S.; Liu, D.; Endy, D. Definitive demonstration by synthesis of genome annotation completeness. Proc. Natl. Acad. Sci. USA 2019, 116, 24206-24213. [CrossRef] [PubMed]

43. Xu, L.; Faruqu, F.N.; Liam-Or, R.; Abu Abed, O.; Li, D.; Venner, K.; Errington, R.J.; Summers, H.; Wang, J.T.; Al-Jamal, K.T. Design of experiment (DoE)-driven in vitro and in vivo uptake studies of exosomes for pancreatic cancer delivery enabled by copper-free click chemistry-based labelling. J. Extracell. Vesicles 2020, 9, 1779458. [CrossRef] [PubMed]

44. Wang, X.; Cao, X.; Liu, H.; Guo, L.; Lin, Y.; Liu, X.; Xiong, Y.; Ni, K.; Yang, F. Effects of Lactic Acid Bacteria on Microbial Metabolic Functions of Paper Mulberry Silage: A BIOLOG ECO Microplates Approach. Front. Microbiol. 2021, 12, 689174. [CrossRef] [PubMed]

45. Lu, W.J.; Wang, H.T.; Nie, Y.F.; Wang, Z.C.; Huang, D.Y.; Qiu, X.Y.; Chen, J.C. Effect of inoculating flower stalks and vegetable waste with ligno-cellulolytic microorganisms on the composting process. J. Environ. Sci. Health B 2004, 39, 871-887. [CrossRef] [PubMed]

46. Ghodsalavi, B.; Ahmadzadeh, M.; Soleimani, M.; Madloo, P.B.; Taghizad Farid, R. Isolation and characterization of rhizobacteria and their effects on root extracts of Valeriana officinalis. Aust. J. Crop. Sci. 2013, 7, 338-344.

47. Kotasthane, A.; Agrawal, T.; Kushwah, R.; Rahatkar, O.V. In-vitro antagonism of Trichoderma spp. against Sclerotium rolfsii and Rhizoctonia solani and their response towards growth of cucumber, bottle gourd and bitter gourd. Eur. J. Plant Pathol. 2015, 141, 523-543. [CrossRef]

48. Yuan, C.L.; Mou, C.X.; Wu, W.L.; Guo, Y.B. Efect of diferent fertilization treatments on indole-3-acetic acid producing bacteria in soil. J. Soils Sediments 2011, 11, 322-329. [CrossRef]

49. Kelel, M.; Abera, G.; Yisma, A.; Molla, B.; Gebre, N.; Adugna, T.; Wesse, G. Isolation of phosphate solubilizing bacteria from acacia tree rhizophere soil. J. Microbiol. Biotech. Res. 2014, 4, 9-13.

50. Keneni, A.; Assefa, F.; Prabu, P.C. Isolation of phosphate solubilizing bacteria from the rhizosphere of faba bean of Ethiopia and their abilities on solubilizing insoluble phosphates. J. Agric. Sci. Technol. 2010, 12, 79-89.

51. Himpsl, S.D.; Mobley, H.L.T. Siderophore Detection Using Chrome Azurol S and Cross-Feeding Assays. Methods Mol. Biol. 2019, 2021, 97-108. [CrossRef]

52. Rahal, E.A.; Kazzi, N.; Kanbar, A.; Abdelnoor, A.M.; Matar, G.M. Role of rifampicin in limiting Escherichia coli O157:H7 Shiga-like toxin expression and enhancement of survival of infected BALB/c mice. Int. J. Antimicrob. Agents 2011, 37, 135-139. [CrossRef] [PubMed] 
53. Brillard, J.; Ribeiro, C.; Boemare, N.; Brehélin, M.; Givaudan, A. Two Distinct Hemolytic Activities in Xenorhabdus nematophila Are Active against Immunocompetent Insect Cells. Appl. Environ. Microbiol. 2001, 67, 2515-2525. [CrossRef] [PubMed]

54. Farhangi-Abriz, S.; Torabian, S. Antioxidant enzyme and osmotic adjustment changes in bean seedlings as affected by biochar under salt stress. Ecotoxicol. Environ. Saf. 2017, 137, 64-70. [CrossRef] [PubMed]

55. Zhou, H.-L.; Zhang, R.; Anand, P.; Stomberski, C.; Qian, Z.; Hausladen, A.; Wang, L.; Rhee, E.P.; Parikh, S.M.; Karumanchi, S.A.; et al. Metabolic reprogramming by the S-nitroso-CoA reductase system protects against kidney injury. Nature 2019, 565, 96-100. [CrossRef]

56. Varoquaux, N.; Cole, B.; Gao, C.; Pierroz, G.; Baker, C.R.; Patel, D.; Madera, M.; Jeffers, T.; Hollingsworth, J.; Sievert, J.; et al. Transcriptomic analysis of field-droughted sorghum from seedling to maturity reveals biotic and metabolic responses. Proc. Natl. Acad. Sci. USA 2019, 116, 27124-27132. [CrossRef]

57. Buitrago, L.; Langdon, W.Y.; Sanjay, A.; Kunapuli, S.P. Tyrosine phosphorylated c-Cbl regulates platelet functional responses mediated by outside-in signaling. Blood 2011, 118, 5631-5640. [CrossRef] 